\title{
下顎骨骨折に対する顥間固定後の開口障害についての臨床的検討
}

\author{
田代貴之・田中信幸・柳”沢達雄・冨塚謙一 \\ 安藤壽勇・君島 裕・内出尚里・塩谷健一 \\ 吉増秀實・天笠光雄
}

\section{Evaluation of trismus after maxillomandibular fixation for mandibular fractures}

\author{
Takayuki TAshiro - Nobuyuki TANAKa - Tatsuo Yanagisawa \\ Kenichi Tomitsuka • Hisao Ando • Yutaka Kimijima • Naori Uchide \\ Kenichi Shionoya • Hidemi Yoshimasu • Teruo Amagasa
}

\begin{abstract}
This retrospective study about trismus after the release of maxillomandibular fixation was performed in 103 cases of mandibular fracture in our department and the following results were obtained:

1. Most cases of trismus were recovered by 12 weeks after the relase of fixation. However, in the group below the age of 30 years recovery took place within 8 weeks.

2. Trismus was most frequently found in multiple-line fractures.

3. Trismus occurred less frequently in open reduction cases than in closed reduction cases.

4. The relative frequency of trismus was unaffected by the presence or absence of condylar fracture.
\end{abstract}

5. There was no definitive relationship between the period of maxillomandibular fixation and the occurrence of trismus.

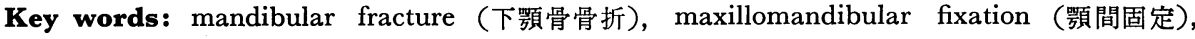 trismus（開口障害）

緒

言

䫇顔面骨骨折の治療飞颃いて，顎間固定は重要な処置

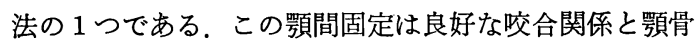
の固定に有用である反面，長期間の固定による弊害とし $\tau$, 固定期間中の精神的苦痛, 術後の体重減少, 開口障 害の残存などが近年指摘されている1,2)。今回われわれ は䫕間固定と術後の開口障害との関連について, 当科に 括ける下顎骨骨折症例を対象に検討を行ったので報告す る.

東京医科歯科大学齿学部口腟外科学第一講座 (主任 : 天笠光雄教授)

The First Department of Oral and Maxillofacial Surgery, Faculty of Dentistry, Tokyo Medical and Dental University (Chief: Prof. Teruo Amagasa) 受付日：平成 4 年 9 月 7 日

\section{対 象 症 例}

1977年 1 月から1990年12月の 14 年間に当科を受診した 顎顔面骨骨折症例は 753 例で, 顎間固定を行った下顎骨 骨折症例は 169 例であった。今回はこの下箱骨骨折症例 中, 詳細な検索が可能であった103例を対象症例とした。 対象症例中, 非観血的処置例は91例，観血的処置例は 12 例であった。

\section{研 究 方 法}

対象症例について，澦間固定除去後の開口障害とその 回復までの期間を, 年齢, 性, 骨折部位, 顎間固定期間 との関連について検討した。 なお，開口障害については, 山口゙)をはじめとして通常用いられている開口度 $40 \mathrm{~mm}$ 末満を開口障害ありと判定した。開口訓練については， 患者に手指による開口訓練をするように説明した。 
表 1 年齢別・性別，顎間固定除去後の開口障害

\begin{tabular}{|c|c|c|c|c|c|c|c|c|}
\hline \multirow{2}{*}{$\begin{array}{c}\text { 年齢別 } \\
\text { (歳) }\end{array}$} & \multirow{2}{*}{$\begin{array}{l}\text { 性 } \\
\text { 別 }\end{array}$} & \multirow{2}{*}{$\begin{array}{l}\text { 顎間固定 } \\
\text { 除 去時 } \\
\text { 開口障害 } \\
(-)\end{array}$} & \multicolumn{5}{|c|}{$\begin{array}{l}\text { 顎間固定除去時開口障害（+）の症例が開 } \\
\text { 口障害 (-) となる間 (週) }\end{array}$} & \multirow{2}{*}{ 計 } \\
\hline & & & $\sim 4$ & $\sim 8$ & $\sim 12$ & $13 \sim$ & 小計 & \\
\hline \multirow{2}{*}{$10 \sim 19$} & 男 & 7 & 6 & 5 & - & 4 & 15 & 22 \\
\hline & 女 & 1 & 3 & 4 & 2 & 1 & 10 & 11 \\
\hline \multirow{2}{*}{$20 \sim 29$} & 男 & 11 & 11 & 8 & 4 & 5 & 28 & 39 \\
\hline & 女 & 1 & 2 & 1 & 1 & - & 4 & 5 \\
\hline \multirow{2}{*}{$30 \sim 39$} & 男 & - & 4 & 1 & 2 & - & 7 & 7 \\
\hline & 女 & - & 1 & - & 1 & - & 2 & 2 \\
\hline \multirow{2}{*}{$40 \sim 49$} & 男 & 2 & - & 3 & - & $3^{*}$ & 6 & 8 \\
\hline & 女 & 2 & - & - & - & 1 & 1 & 3 \\
\hline \multirow{2}{*}{$50 \sim 59$} & 男 & 3 & - & 1 & 1 & - & 2 & 5 \\
\hline & 女 & - & - & - & - & - & - & 0 \\
\hline \multirow{2}{*}{$60 \sim 69$} & 男 & - & - & - & 一 & 1 & 1 & 1 \\
\hline & 女 & & - & - & - & - & - & 0 \\
\hline \multirow{3}{*}{ 計 } & 男 & 23 & 21 & 18 & 7 & 13 & 59 & 82 \\
\hline & 女 & 4 & 6 & 5 & 4 & 2 & 17 & 21 \\
\hline & & 27 & 27 & 23 & 11 & 15 & 76 & 103 \\
\hline
\end{tabular}

* 開口障害の回復しないまま通院終了した 1 例を含む

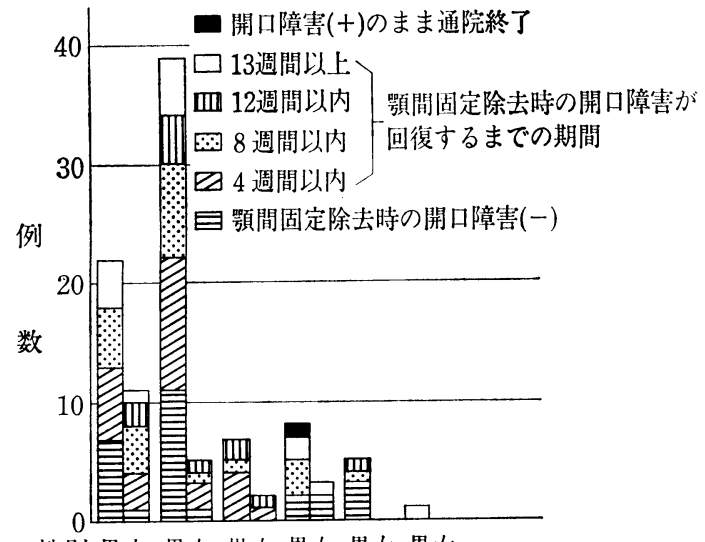

性別男女男女男女男女男女男女

年齢 $10 \sim 20 \sim 30 \sim 40 \sim 50 \sim 60 \sim$

図 1 年齢別・性別，顎間固定除去後の開口障害

$$
\text { 結果 }
$$

1. 年齢別, 性別の顎間固定除去後の開口障害（表 1, 図1)

顎間固定除去時に 開口障害の 認められたものは, 103 例中76例 $(73.8 \%)$ であった.

性別では, 男性82例中59例 (72.0\%), 女性21例中17例 (81.0\%) にみられた.

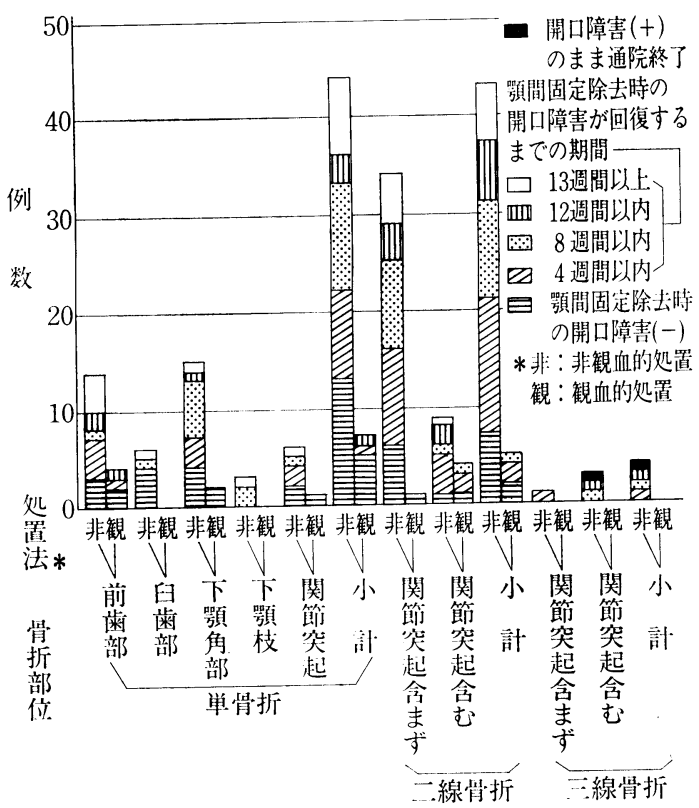

図 2 下顎骨骨折部位別, 顎間固定除去後の開口障 害

次に，術後の開口障害が 回復するまでの 期間をみる と, 76例中 61 例 $(80.3 \%)$ が12週間以内に回復した. 10 歳代, 20 歳代の若年者では57例中 40 例 $(70.2 \%)$ が 8 週 
表 2 下顎骨骨折部位別，顎間固定除去後の開口障害（症例数）

\begin{tabular}{|c|c|c|c|c|c|c|c|c|c|}
\hline & \multirow[t]{2}{*}{ 骨折部位 } & \multirow{2}{*}{$\begin{array}{l}\text { 処 } \\
\text { 置 } \\
\text { 法* }\end{array}$} & \multirow{2}{*}{$\begin{array}{l}\text { 顎間固定 } \\
\text { 除 去 時 } \\
\text { 開口障害 } \\
(-)\end{array}$} & \multicolumn{5}{|c|}{$\begin{array}{l}\text { 顎間固定除去時開口障害 (十) の症例が開 } \\
\text { 口障害 (-) となるきでの期 }(\text { 間) }\end{array}$} & \multirow[t]{2}{*}{ 計 } \\
\hline & & & & $\sim 4$ & $\sim 8$ & $\sim 12$ & $\sim 13$ & 小計 & \\
\hline \multirow{12}{*}{$\begin{array}{l}\text { 単 } \\
\text { 骨 } \\
\text { 折 }\end{array}$} & \multirow{2}{*}{ 前 歯 部 } & 非 & 3 & 4 & 1 & 2 & 4 & 11 & 14 \\
\hline & & 観 & 2 & 1 & - & 1 & - & 2 & 4 \\
\hline & \multirow{2}{*}{ 臼 歯 部 } & 非 & 4 & - & 1 & - & 1 & 2 & 6 \\
\hline & & 観 & - & - & - & - & - & - & 0 \\
\hline & \multirow{2}{*}{ 下顎角部 } & 非 & 4 & 3 & 6 & 1 & 1 & 11 & 15 \\
\hline & & 観 & 2 & - & - & - & - & - & 2 \\
\hline & \multirow{2}{*}{ 下顎 枝 } & 非 & - & - & 2 & - & 1 & 3 & 3 \\
\hline & & 観 & - & - & - & - & - & - & 0 \\
\hline & \multirow{2}{*}{ 関節突起 } & 非 & 2 & 2 & 1 & - & 1 & 4 & 6 \\
\hline & & 観 & 1 & - & - & - & - & - & 1 \\
\hline & \multirow{2}{*}{ 小 計 } & 非 & 13 & 9 & 11 & 3 & 8 & 31 & 44 \\
\hline & & 観 & 5 & 1 & - & 1 & - & 2 & 7 \\
\hline \multirow{6}{*}{$\begin{array}{l}\text { 二 } \\
\text { 線 } \\
\text { 骨 } \\
\text { 折 }\end{array}$} & 関節突起 & 非 & 6 & 10 & 9 & 4 & 5 & 28 & 34 \\
\hline & 含まず & 観 & 1 & - & - & - & - & - & 1 \\
\hline & 関節突起 & 非 & 1 & 4 & 1 & 2 & 1 & 8 & 9 \\
\hline & 含点 & 観 & 1 & 2 & 1 & - & - & 3 & 4 \\
\hline & \multirow{2}{*}{ 小 計 } & 非 & 7 & 14 & 10 & 6 & 6 & 36 & 43 \\
\hline & & 観 & 2 & 2 & 1 & - & - & 3 & 5 \\
\hline \multirow{6}{*}{$\begin{array}{l}\text { 三 } \\
\text { 線 } \\
\text { 骨 } \\
\text { 折 }\end{array}$} & 関節突起 & 非 & - & 1 & - & - & - & 1 & 1 \\
\hline & 含まず & 観 & - & 一 & - & - & - & - & 0 \\
\hline & 関節突起 & 非 & - & - & 1 & 1 & $1 * *$ & 3 & 3 \\
\hline & 含名 & 観 & - & - & - & - & - & - & 0 \\
\hline & \multirow{2}{*}{ 小 計 } & 非 & - & 1 & 1 & 1 & 1 & 4 & 4 \\
\hline & & 観 & - & - & - & - & - & - & 0 \\
\hline & \multirow{2}{*}{ 計 } & 非 & 20 & 24 & 22 & 10 & 15 & 71 & 91 \\
\hline & & 観 & 7 & 3 & 1 & 1 & 0 & 5 & 12 \\
\hline
\end{tabular}

* : 非 : 非観血的処置, 観 : 観血的処置

** : 開口障害の回復しないまま通院終了した症例

間以内に開口障害が回復しているのに対し，30歳以上で は19例中10例（52.6\%）であった。

\section{2. 下顎骨骨折部位別の顎間固定除去後の開口障害(表}

\section{2, 図 2)}

単骨折の場合，非観血的処置例では44例中 31 例 $(70.5$ \%) に開口障害が認められ, 観血的処置例では 7 例中 2 例 $(28.6 \%)$ で認められた，部位別にみてみると，非観 血的処置例 では, 下罰枝骨折は 3 例全例, 前歯部骨折 は 14 例中 11 例 $(78.6 \%)$ ，下頡角部骨折は 15 例中 11 例 $(73.3 \%)$, 関節突起骨折は 6 例中 4 例 $(66.7 \%)$, 目歯部 骨折は 6 例中 2 例 $(33.3 \%)$ 飞開口障害が認められた。
一方, 観血的処置例では, 前歯部骨折で 4 例中 2 例に開 口障害が認められたが，下顎角部骨折 2 例と関節突起骨 折 1 例では, 開口障害は認められなかった。

また，発現した開口障害は非観血的処置例では31例中 23 例 $(74.2 \%)$ ，観血的処置例では 2 例全例が 12 週間以内 に回復した.

二線骨折の場合，非観血的処置例 では 43 例中 36 例 (83.7\%) 飞開口障害が認められ，観血的処置例では 5 例 中 3 例 $(60.0 \%)$ で認められた。関節突起骨折を含むか 否かで分類し検討すると，非観血的処置例では，関節突 起骨折を含をないものは 34 例中 28 例 $(82.4 \%)$ に開口 


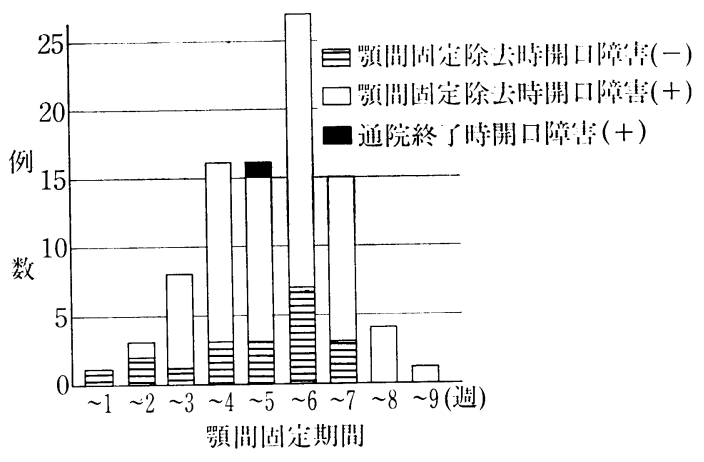

図 3 顎間固定期間と開口障害（非観血的処置例）

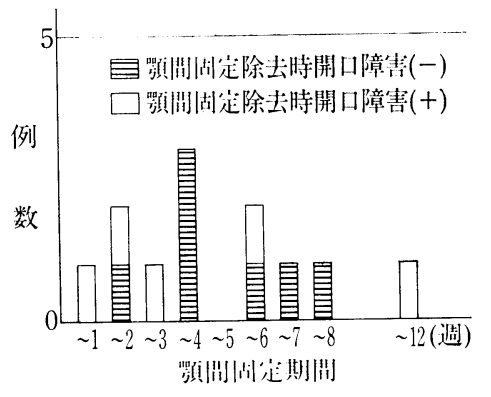

図 4 顎間固定期間と開口障害 （観血的処置例）

障害が認められ, 関節突起骨折を含むものは 9 例中 8 例 (88.9\%)で認められた。一方, 観血的処置例では, 関節 突起骨折を含まない 1 例では開口障害が認められなかっ たが，関節突起骨折を含むものは 4 例中 3 例 $(75.0 \%)$ で開口障害が認められた。

発現した開口障害は，非観血的処置例では36例中 30 例 $(83.3 \%)$, 観血的処置例では 3 例全例が 12 週間以内に回 復した。

三線骨折は，非観血的处置例のみであり，4例すべて に開口障害が認められた。このらち 3 例は 12 週間以内に 回復したが，関節突起骨折を含む 1 例は，12週間を経て な打開口障害を有し，その後通院せず，経過不明の症例 である.

\section{3. 顎間固定期間と開口障害（図 3，表 4)}

顎間固定期間は $1 \sim 12$ 週間にわたり, 患者の年齢や骨 折片の変位程度などにより異なるが，その平均は，非観 血的処置例では5. 3 週間, 観血的処置例では4.9週間であ った。

開口障害の有無と顎間固定期間との関連について検討 すると, 非観血的処置例に括いては，4〜 7 週間の㖽間 固定症例では約 $80 \%$ に開口障害が発現して拉り，8週間 以上の長期の顎間固定症例の 5 例すべてに開口障害が認
表 3 顎間固定期間別, 顎間固定除去後の開口障害 (症例数)

\begin{tabular}{|c|c|c|c|c|c|c|}
\hline \multirow[t]{2}{*}{$\begin{array}{l}\text { 顎間固定 } \\
\text { 期 } \\
\text { (週) }\end{array}$} & \multirow[t]{2}{*}{$\begin{array}{l}\text { 処 } \\
\text { 置 } \\
\text { 法* }\end{array}$} & \multicolumn{4}{|c|}{$\begin{array}{l}\text { 顎間固定除去時開口障害 } \\
(+) \text { 症例が開口障害 } \\
(\text { (一) となるまでの期間 } \\
\text { (週) }\end{array}$} & \multirow[t]{2}{*}{ 計 } \\
\hline & & $\sim 4$ & $\sim 8$ & $\sim 12$ & $13 \sim$ & \\
\hline \multirow{2}{*}{1} & 非 & - & - & - & - & 0 \\
\hline & 観 & - & 1 & - & - & 1 \\
\hline \multirow{2}{*}{2} & 非 & - & - & 1 & - & 1 \\
\hline & 観 & 1 & - & - & - & 1 \\
\hline \multirow{2}{*}{3} & 非 & 5 & - & 2 & - & 7 \\
\hline & 観 & 1 & - & - & - & 1 \\
\hline \multirow{2}{*}{4} & 非 & 5 & 3 & 3 & 2 & 13 \\
\hline & 観 & - & - & - & - & - \\
\hline \multirow{2}{*}{5} & 非 & 5 & 3 & 2 & 3 & 13 \\
\hline & 観 & - & - & - & - & - \\
\hline \multirow{2}{*}{6} & 非 & 6 & 12 & - & 2 & 20 \\
\hline & 観 & 1 & - & - & - & 1 \\
\hline \multirow{2}{*}{7} & 非 & 1 & 4 & 2 & 5 & 12 \\
\hline & 観 & - & - & - & - & - \\
\hline \multirow{2}{*}{8} & 非 & 1 & - & - & 3 & 4 \\
\hline & 観 & - & - & - & - & - \\
\hline \multirow{2}{*}{9} & 非 & 1 & - & - & - & 1 \\
\hline & 観 & - & - & - & - & - \\
\hline \multirow{2}{*}{12} & 非 & - & - & - & - & - \\
\hline & 観 & - & - & 1 & - & 1 \\
\hline \multirow{2}{*}{ 計 } & 非 & 24 & 22 & 10 & 15 & 71 \\
\hline & 観 & 3 & 1 & 1 & - & 5 \\
\hline
\end{tabular}

* 非 : 非観血的処置

* 観：観血的処置

められた． 観血的処置例では， $4 \sim 8$ 週間の顎間固定 7 例中 1 例のみに開口障害が認められたが， 3 週間以内の 短期間の 顎間固定 4 例中 3 例にも開口障害が 認められ た.

\section{4. 顎間固定除去後の開口障害の回復（表 3）}

非観血的処置例では顎間固定除去後 4 週間以内に開口 障害の回復したものが71例中 24 例， 4 週間をこえて 8 週 間以内が 22 例, 8 週間をこえて 12 週間以内が 10 例であっ た. 顎間固定期間が 9 週間の 1 例は除去後 4 週間以内に 回復しているが, $7 \sim 8$ 週間の症例では回復までに比較 的長期間を有していた。

顎間固定期間が 2 週間以内の 1 症例は治療に対して非 協力的であり, 術後の開口練習に対しても消極的で, 開 口障害の回復までに12週を要した. 観血的処置例では, 4 週間以内に開口障害の回復したものが 5 例中 3 例であ 
ク，12週間以内には全例が回復した。

\section{考察}

1977年 1 月から1990年12月までの14年間に当科を受診

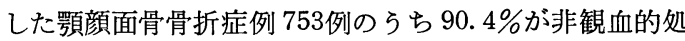
置を受けており，その $54.1 \%$ 顎間固定が 行われてい た。また観血的処置例に打いても，術後 $51.4 \%$ に顎間固 定が行われていた。

骨折による咬合の変位が著しい場合, 当科では牽引療 法によりある程度咬合が回復された段階で顎間固定を施 すようにしているが，それでも変位が著しい場合顎間固 定期間はやや長めにする傾向であった。

顎間固定を長期間行った場合，顎間固定除去後の開口 障害が大きな問題である.

そこで今回われわれは，口腔外科領域で扱ら顎骨骨折 として最も頻度の高い下顎骨骨折症例を対象とし，顎間 固定除去後の開口障害について検討した。

開口障害の回復にかかる期間は，30歳未満の若年者の 方が短い傾向が認められた。これは，若年者の方が適応 能力が高いことを示していると思われた。 つまり，若年 者においては，顎間固定が顎関節および周囲の筋肉に影 響して開口障害を生じやすいが，顎間固定除去後の開口 度の回復も早いといらことが示唆された。

次に，骨折部位と開口障害との関連については，非観 血的処置例，観血的処置例ともに，骨折線が増加すると 開口障害の発現する頻度が 増加する傾向を示した。 た，症例数は少ないが，非観血的処置例より観血的処置 例の方が，顎間固定除去時点での開口障害の発現が少な かった，観血的処置において，プレート固定，ワイヤー 固定，またプレート，ワイヤーの数により顎間固定期間 や予後が左右されることは当然推測され，今後の検討課 題である．下顎骨には種々の筋が，種々の方向へ力を加 えるかたらで付着して打り，それらの複雑な協調のら党 に下顎運動は成り立っている ${ }^{4)}$. 下顎骨骨折はその協調 を崩すものであり，そのため，骨折線数が増加すると， 咬合の変位も複雑化するとともに，正常な下顎運動を阻 害する程度も大きくなるのではないかと考えられる。ま た，観血的処置，非観血的処置にかかわらず，適切な整 復固定処置がなされれば予後は良好となりえるが，観血 的処置による方が，より早期に強固な整復固定を得やす く，顎間固定除去後の開口練習が比較的容易なため，開 口障害も早期に回復するものと考えられる.

前崡部，下顎角部の骨折症例では70\%以上，下顎枝部 では全例に顎間固定除去時に開口障害が発現したが，こ れらの部位の骨折に拈いては，顕著な咬合の变位を生じ る症例が多いためである。また，関節突起骨折について は，関節そのものの骨折であるので，開口障害は発現し やすいと考えられるが，小野ら ${ }^{5)}$ の報告にみられるよう
に，その 開口障害は 顎間固定除去後短期間のものであ り，開口訓練により回復可能である。

次に顎間固定期間と開口障害についてみると，固定期 間の長さと開口障害の有無については，明確な関連は認 められなかった。この点に関しては, 森永ら ${ }^{6}$ が関節突起 骨折について同様の報告をして招り，Walker ${ }^{7)}$, Boyne ${ }^{8)}$ は顎間固定が関節突起の再形成に影響を与えることは少 ないと述べている。また，山口 ${ }^{3)}$ は 6 週間以内の顎間固 定期間では，固定期間と予後との間に相関性は認められ なかったと報告して和り今回の検索結果もこれを支持す るものである。しかし，Amaratunga9) は，顎間固定期 間が 3 週間と 5 週間とでは， 6 か月後の時点での開口度 に有意に差があり，5週間の顎間固定の症例に開口障害 が認められると述べており，Cawood ${ }^{1)}$, Wood ${ }^{10)}$ と同様 に，顎間固定期間の短縮をはかるべきだとしている。

組織学的には Glineburg ら ${ }^{11)}$ が, 8 週間の顎間固定よ り, 霊長類の下顎頭の 軟骨の薄化, 断裂などが認めら れ，顎間固定除去後 8 か月でその軟骨の厚みは徐々に戻 るが，断裂は完全には戻らないと報告し，島原 ${ }^{12)}$ は関節 突起骨折を起こしたラットでは 2 週間以上の顎間固定に より変形治㾑による開口障害などの後遺症が発現し, 顎 間固定が長期間になる程, 開口障害の程度は強く長く持 続すると述べている，また，今上 ${ }^{13)} は ，$ 関節円板を切離 摘出し，下顎窩および下顎頭軟骨層を挫滅損傷した猿に 顎間固定を行ったところ，顎間固定後早期より治痊機転 は始まるが，2週以降に拈いて線維性強直の所見が増大 し，その後次第に顎関節強直の度合いが強まっていくこ とを報告し, 顎間固定 2 週以降に積極的に開口訓練を行 うのが合理的だと述べている。このことは，骨折に限ら ず，顎関節部に何らかの損傷が生じた場合には，比較的 短期間の顎間固定によっても開口障害が発現することを 示唆している。

さらに，顎間固定除去後の開口障害が回復するまでの 期間をみると，観血的処置例では12週間以内に開口障害 が全例回復して扣り，同時点で非観血的処置例では約 80\%が回復している。これは，観血的処置例では，早期 に骨折片の整復がなされ，周囲の筋組織なども，それだ け早期にもとの状態へ回復されることが予測され，その ため開口障害の回復も短期間になると考えられる。さら に，非観血的処置例では，術後の開口練習を積極的に受 け入れない症例も多く，今回の検索では15例が回復まで に13週以上必要であった。開口障害消失までの期間につ いては, 顎間固定除去後12週間を一応の目安とすること が妥当と考劣られる。

以上より，観血的処置によれば，より重度な骨折に対 応できるほか，顎間固定期間の短縮も図れると言われて いるが，非観血的処置においても，十分な期間の顎間固 定により多くの顎顔面骨骨折に対応することも可能であ り，その後の開口障害も回復可能であるといえる。すな 
わち, 骨折に対する保存的治療は, ゴム牽引などによる 骨片の変位の整復と顎間固定により, 手術を受け入れら れない骨折患者にも対処し得る。しかし, 長期の顎間固 定は，患者に対し心身ともに苦痛を与えることも否定で きない. 喜田 ${ }^{14)}$ は, 振動の伝達性をコヒーレンス関数に より解析することで骨折の治瘉を客観的に判定する方法 を報告しているが，そのような顎顔面骨折の治癒と関連 して顎間固定除去の時期を見極める適切な手段を検討す ベきものと考える.

\section{結語}

1977年から1990年の当科に掞いて，顎間固定を行った 下顎骨骨折症例 103 例について, 術後の開口障害の発現 と回復との関係について検討し, 以下の結果を得た.

1. 顎間固定除去 12 週後までに開口障害の多くは回復 したが，30歳未満の若年者では 8 週以内での回復が多く みられた。

2. 骨折線数が多いほど, 顎間固定除去時の 開口障害 の発現は多く認められた。

3. 非観血的処置例より観血的処置例 の方が，顎間固 定除去時の開口障害の発現は少なかった.

4. 顎間固定除去時の 開口障害の発現に, 関節突起骨 折を含むか否かでの差異は認められなかった。

5. 顎間固定期間と顎間固定除去時の 開口障害の発現 との明確な関連は認められなかった.

本論文の要旨は, 平成 3 年 10 月 2 日, 第 36 回日本口 腔外科学会総会（於：吹田市文化会館）に拈いて発表し た。

\section{引用 文 献}

1) Cawood, J.I.: Small plate osteosynthesis of mandibular fractures. British J Oral Maxillofac Surg 23: 77-91 1985.

2) Dodson, T.B., Perrott, D.H., et al.: Fixation of mandibular fractures: A comparative ana- lysis of rigid internal fixation and standard fixation techniques. J Oral Maxillofac Surg 48: 362-366 1990.

3）山口一文：顎関節突起骨折の非観血的治療に関 する研究. 日口外誌 31：2120-2134 1985.

4) 上野 正, 伊藤秀夫監修：最新口腔外科学. 第 3 版, 医齿薬出版, 東京, 1986, 594-617頁.

5）小野尊睦, 古川哲夫, 他：顎関節突起骨折の遠 隔成績について。 日外誌 16：387-395 1970.

6）森永宏喜, 木野孔司, 他: 過去 12 年間の当科に 打怕る下顎骨関節突起骨折の臨床統計的観察. 日口外誌 $36: 2055-20681990$.

7) Walker, R.V.: Traumatic mandibular condylar fracture dislocations. Effect on growth in the Macaca rhesus monkey Am J Surg 100: 850-863 1960.

8) Boyne, P.J.: Osseous repair and mandibular growth after subcondylar fractures. J Oral Surg 25: 300-309 1967.

9) Amaratunga, N.A.: Mouth opening after release of maxillomandibular fixation in fracture patients. J Oral Maxillofac Surg 45: 3833851987.

10) Wood, G.D.: Assessment of function following fracture of the mandible. $\mathrm{Br}$ Dent $\mathrm{J}$ 149: 137-141 1980.

11) Glineburg, R.W., Laskin, D.M., et al.: The effects of immobilization on the primate temporomandibular joint: A histologic and histochemical study. J Oral Maxillofac Surg 40: 3-8 1982.

12）島原政司：下顎関節突起骨折治瘾に関する実験 的研究 第 3 編 顎間固定による片側性下顎頸部 骨折治癒の実験的研究. 日口外誌 27：130413231981.

13）今上茂樹：顎関節の機能障害に関する研究. 2 . 顎関節損傷時の機能回復と組織修復過程に顎運 動が及ぼす影響に関する実験 的研 究. 口科誌 26: 431-450 1977.

14）喜田正孝：振動利用コヒーレンス関数解析によ る下顎骨骨折の治瘾判定に関する研究. 日口外 誌 35: 569-588 1989. 